\title{
A Preliminary Scoping Review Study of the Progress of Social Media Adoption as an Educational Tool by Academics in Higher Education.
}

\author{
Eva Perez \\ PhD Scholar \\ Trinity Business School, Trinity College Dublin \\ Dublin, Ireland \\ Mairead Brady \\ Assistant Professor in Marketing \\ Trinity Business School, Trinity College Dublin \\ Dublin, Ireland
}

(C) Eva Perez and Mairead Brady. This work is licensed under the Creative Commons Attribution-NonCommercial-ShareAlike 4.0 International License. To view a copy of this license, visit https://creativecommons.org/licenses/by-nc-sa/4.0/ .

\section{Abstract}

This paper presents a preliminary scoping review exploring the evidence landscape regarding academic staff experiences and perceptions of social media adoption as an educational tool in higher education. The goal of this paper is to examine 10 empirical studies of social media adoption in teaching and learning by academics in preparation for a proposal for a systematic literature review. Consequently, this scoping study assisted in the development of a review protocol which established the inclusion and exclusion criteria for conducting this systematic review at a future date. This paper will present the first stage of carrying out a systematic review: planning the review and presenting the results of the scoping study. The findings of this scoping study revealed that academics are slow in adopting social media within teaching and academics that have adopted the use of social media do so primarily for sharing relevant information and resources easily with students rather than for teaching purposes. Overall, the adoption of social media as an educational tool is faced with many challenges, such as cultural resistance, pedagogical issues, lack of institutional support and time investment. The results also indicate that teaching styles, demographic factors, privacy issues and previous experience can influence academic staff's decision to adopt social media for teaching purposes.

Keywords: Social Media, Teaching and Learning, Higher Education 


\section{Introduction}

The popularity of social networking among millennials, which includes students, has increased dramatically in the past few years because of the advances in Web 2.0 tools and technologies which offer a more convenient and effective way to communicate and interact among social groups (Nkhoma, Cong, Au, Lam, Richardson, Smith and El-Den, 2015). Social Networking Sites (SNSs) such as Facebook, Twitter, YouTube, Wiki, Blogs, and online games, have been widely used for information gathering and dissemination, collaborative learning and online social and professional connections (Cao, Ajjan and Hong, 2013). However, the use of SNSs within higher education is still very new and there is much to be researched in order to develop a better understanding of its use as an academic tool (Prescott, 2014). Much of the research on SNSs has concentrated on student experiences using specific branded social media tools: Twitter (Evans, 2014, Junco, Elavsky \& Heiberger, 2013 and Junco, Heiberger \& Loken, 2011), Facebook (Nkhoma et al., 2015) and YouTube (Jung and Lee, 2015).

A small number of studies have presented some evidence of the use of social media by academics for personal, professional and teaching purposes (Cao, et al., 2013; Manca and Ranieri, 2016a; Manca and Ranieri, 2016b; Manca and Ranieri, 2013). Therefore, the potential adoption of social media as an educational tool has received attention and interest. Despite this increasing interest, there is a lack of research investigating why or why not academics are adopting social media for teaching (Cao, et al., 2013; Prescott, 2014; Sobaih, Moustafa, Ghandforoush, and Khan, 2016; Manca and Ranieri, 2016a).

This paper sets out a novel approach to literature reviews within the educational research literature. It provides a proposal review based on a preliminary scoping study. A scoping review is necessary to assess the relevance and size of the literature and to delimit the subject area (Tranfield, Denyer and Smart, 2003). Findings of this review are presented in the result section of this paper. The methodology section explains the methods and processes used in the first stage of planning for the systematic literature review.

\section{Social media within education}

Social media can be defined as "a group of Internet-based applications that build on the ideological and technological foundations of Web 2.0, and that allow the creation and exchange of User Generated Content" (Kaplan \& Haenlein, 2010, p.61). It is a term that is broadly used and often described by example or not described at all. The 
task of defining social media is made more challenging by the fact that it is constantly in a state of change (Tess, 2013). In the educational research literature, some authors use 'social media' interchangeably with 'social web' (Waycott, Sheard, Thompson, and Clerehan, 2013), or 'social media applications' (Cao et al., 2013). The term most commonly used is 'social networking sites' (SNSs) (Manca and Ranieri, 2013; Manca and Ranieri, 2016a; Manca and Ranieri, 2016b; Tess, 2013; Prescott, 2014; Scott, 2013).

Despite the terminological differences, 'social media' refers to a variety of applications which enable the creation, sharing, discussing and commenting on digital content (Manca and Ranieri, 2016b). These applications can be classified into more specific categories: collaborative projects (wikis), blogs, content communities (e.g. YouTube/Vimeo), social networking sites (e.g. Facebook), virtual game worlds, and virtual social worlds (Kaplan and Haenlein, 2010). Combining all dimensions of social media leads to a classification that can be visualised in Table 1.

Table 1: Classification of SNSs (Social Networking Sites)

\begin{tabular}{|l|l|l|l|}
\hline $\begin{array}{l}\text { Social/personal } \\
\text { SNS }\end{array}$ & $\begin{array}{l}\text { Professional or } \\
\text { academic SNS }\end{array}$ & $\begin{array}{l}\text { Content writing } \\
\text { and delivery SNS }\end{array}$ & $\begin{array}{l}\text { Collaborative } \\
\text { projects SNS }\end{array}$ \\
\hline Twitter & Linkedln & Blogs & Wikis \\
Facebook & Research Gate & Podcasts & Forums \\
Instagram & Academia.edu & YouTube/Vimeo & \\
& & SlideShare & \\
\hline
\end{tabular}

Adapted from Manca and Raineri (2016b), Cao et al. (2013) and Kaplan and Haenlein (2010)

Manca and Raineri (2016a) found a range of uses for SNSs including: personal use for connecting with family and friends; Teaching use as part of a course you are teaching (researching a topic, including in a lecture, as part of a student assignment, etc.); and (non-teaching) professional use for connecting with colleagues and staying up to date on areas of professional interest. According to Manca and Ranieri (2016b), even if faculty members have access to information technologies both at home and on campus, they mainly use these technologies for personal purposes and not for teaching purposes in their courses. 
In order to meaningfully incorporate social media into teaching, it is imperative to establish what has been done successfully and what can be further improved. However, no up to date empirical review has been conducted in regard to this subject in recent years. The experiences and perceptions of academics' use of social media in higher education is underrepresented in the literature. So far, no systematic literature review has been conducted to provide a critical review of academics' adoption challenges. Most reviews to date mainly focus on exploring students' experiences and perceptions of social media use (Manca and Ranieri, 2013; Tess, 2013; Manca and Ranieri, 2016c).

\section{Previous reviews of social media in educational contexts}

For the corpus of empirical studies, only peer-reviewed journal articles were included. However, review articles of social media use were also read. The information within these review articles was used as part of the background information that informed this study.

Three relevant prior reviews of social media in educational contexts are summarized in Table 2.

Table 2: Characteristics of the systematic literature reviews

\begin{tabular}{|c|c|c|c|c|c|c|c|}
\hline Year & Study & Journal & $\begin{array}{l}\text { Articles } \\
\text { Reviewed }\end{array}$ & Keywords & Databases & $\begin{array}{l}\text { Papers } \\
\text { Published }\end{array}$ & $\begin{array}{l}\text { Papers } \\
\text { focus }\end{array}$ \\
\hline 2013 & $\begin{array}{l}\text { Manca and } \\
\text { Ranieri } \\
\text { Is it a tool } \\
\text { suitable for } \\
\text { learning? A } \\
\text { critical review } \\
\text { of the literature } \\
\text { on Facebook } \\
\text { as a } \\
\text { technology- } \\
\text { enhanced } \\
\text { learning } \\
\text { environment }\end{array}$ & $\begin{array}{l}\text { Journal of } \\
\text { Computer } \\
\text { Assisted } \\
\text { Learning } \\
\text { Rank } 23\end{array}$ & 23 & Facebook & $\begin{array}{l}\text { ERIC, } \\
\text { ERC } \\
\text { Web of } \\
\text { Science, } \\
\text { Scopus }\end{array}$ & 2011-2012 & $\begin{array}{l}\text { Students } \\
\text { and staff } \\
\text { focused. } \\
\text { Specifically } \\
\text { investigating } \\
\text { Facebook. }\end{array}$ \\
\hline
\end{tabular}




\begin{tabular}{|c|c|c|c|c|c|c|c|}
\hline 2013 & $\begin{array}{l}\text { Tess } \\
\text { The role of } \\
\text { social media in } \\
\text { higher } \\
\text { education } \\
\text { classes (real } \\
\text { and virtual) - } \\
\text { A literature } \\
\text { review }\end{array}$ & $\begin{array}{l}\text { Computers } \\
\text { in Human } \\
\text { Behavior } \\
3^{*}\end{array}$ & 24 & $\begin{array}{l}\text { Facebook, } \\
\text { Higher } \\
\text { Education, } \\
\text { Social } \\
\text { Media, } \\
\text { Social } \\
\text { Media in } \\
\text { Education, } \\
\text { Myspace, } \\
\text { Linkedln, } \\
\text { Web 2.0, } \\
\text { Social } \\
\text { Networking } \\
\text { Sites and } \\
\text { Blogs }\end{array}$ & $\begin{array}{l}\text { Web of } \\
\text { Science, } \\
\text { EBSCO } \\
\text { host, } \\
\text { ERIC }\end{array}$ & 2008-2012 & $\begin{array}{l}\text { Student and } \\
\text { staff focused. } \\
\text { Social Media } \\
\text { and its role in } \\
\text { higher } \\
\text { education. } \\
\text { Facebook, } \\
\text { Linkedln, } \\
\text { Myspace, } \\
\text { and Blogs. }\end{array}$ \\
\hline 2016 & $\begin{array}{l}\text { Manca and } \\
\text { Ranieri } \\
\text { (2016c) } \\
\text { Is Facebook } \\
\text { still a suitable } \\
\text { technology- } \\
\text { enhanced } \\
\text { learning } \\
\text { environment? } \\
\text { An updated } \\
\text { critical review } \\
\text { of the literature } \\
\text { from } 2012 \text { to } \\
2015 \text {. }\end{array}$ & $\begin{array}{l}\text { Journal of } \\
\text { Computer } \\
\text { Assisted } \\
\text { Learning } \\
\text { Rank } 23\end{array}$ & 147 & Facebook & $\begin{array}{l}\text { ERIC, ERC } \\
\text { Web of } \\
\text { Science, } \\
\text { Scopus }\end{array}$ & 2012-2015 & $\begin{array}{l}\text { Student and } \\
\text { staff focused. } \\
\text { Specifically } \\
\text { investigating } \\
\text { Facebook. }\end{array}$ \\
\hline
\end{tabular}

Of the 24 empirical studies related to the adoption of social media as an educational tool, examined by Tess (2013) only 3 focused specifically on academics, with the rest focused on student's perceptions. His findings show that academics are slow in adopting social media as an educational tool and those who have adopted SNSs in an academic environment are in an experimental stage of its implementation. The reason for this may be that social media adoption is a choice made by the academic staff rather than the institution. Hence it may more of a trial that lends itself to action research and, ultimately, to more questions.

Manca and Ranieri (2013) reviewed 23 empirical studies on the use of Facebook as an educational tool. All of these studies were published between 2011 and 2012 and 
only 3 studies were focused on academics. The results showed both that pedagogical uses of Facebook have only been moderately implemented in educational contexts and that there are many barriers preventing full adoption of Facebook as an educational tool. These barriers include; implicit institutional, teacher and student pedagogies, and cultural issues. In cases where Facebook was used in educational contexts, it was mainly used as a substitute for other Learning Management Systems (LMSs), relying on the familiarity of students with Facebook. When compared to a virtual learning environment, Facebook seemed to be used for delivering content and supporting interactions between students and student-educators. This suggested that social media does not necessarily encourage students to take part in formal education.

In 2016, Manca and Ranieri reviewed Facebook again but this time as a technology enhanced learning tool. All papers in this review were published between 2012 and 2015. This review confirmed again that Facebook is still mostly used as an open alternative to traditional LMSs, although some different academic tasks are now also displayed using Facebook, such as; posting assignments, content delivery, feedback provision, promoting social interaction, collaboration and peer learning according to the principles of socio-constructivist and connectivism frameworks. Almost half of the studies in this review reported pedagogical reasons to use Facebook as an educational tool for formal use in formal settings, or to use Facebook as a supportive and interactive tool for learning in informal uses. The interest in the pedagogical dimension assessed Facebook as an environment that facilitates the interaction between formal education and real life. Facebook links personal experiences and institutional knowledge and enables the connection of course materials to timely realworld examples by supporting self-directed learning.

\section{Methodology}

\section{The present study}

This scoping review is a preliminary study to assist the development of a systematic literature review, with the aim of understanding social media adoption challenges by academics in higher education in the last five years from 2013 to 2017. This scoping study is the first stage of a systematic literature review. The process of systematic review involves three stages: Stage I: planning the review; Stage II: conducting the review; and Stage III: reporting and dissemination. This paper addresses the different phases of Stage I.

Systematic reviews are literature reviews that closely follow a set of scientific methods that aim to limit bias, mainly by attempting to identify, appraise and synthesize all relevant studies in order to answer a particular question. It could be compared to a 
survey - however in this case it involves a survey of the literature, rather than people (Petticrew and Roberts, 2006).

"Systematic reviews in medicine, psychology, and education tend to focus on efficacy of interventions. For example, whether a specific curriculum increases student standardized math test scores. However, reviews in these disciplines also explore causal effects, determine cost effectiveness, and generate theories" (Borrego, Foster and Froyd, 2014; p.48).

Systematic reviews originated in the field of medicine during the 1980s and in the UK in the early 1990s two centres were established to prepare and maintain systematic reviews of the effects of health care interventions - the UK Cochrane Centre in 1993, and the NHS Centre for Reviews and Dissemination in 1994 (Petticrew and Roberts, 2006). The number of systematic reviews published in medicine, psychology, and education has dramatically increased in the past decade (Borrego, Foster and Froyd, 2014). The education sector has sought rigor in its approach to selecting relevant literature to review. As a consequence three organisations have made good progress in creating reviews and developing methods for Systematic Literature Reviews (SLRs): The Campbell Collaboration, the Cochrane Collaboration and the Centre for Evidenceinformed Policy and Practice in Education (EPPI-Centre) (Gough, Oliver and Thomas, 2017).

Cochrane Collaboration has developed a rigorous approach to the preparation of systematic reviews with a structured review model which includes a handbook: Cochrane Handbook for Systematic Reviews of Interventions (last updated March 2011). Preparing a Cochrane review is a complex process and requires making many judgements which may increase the risk of bias in the review process. For instances, review authors' prior knowledge of the results of a study may influence the definition of a systematic review question. Therefore, it is important that the methods used are established and documented at the very beginning of the review. Protocols for Cochrane reviews prior to knowledge of the available studies reduces the impact of biases and promotes transparency of methods and processes (Higgins and Green, 2008).

For this research, ten empirical studies were identified as eligible publications for the preparation of conducting the systematic literature review. The findings of this scoping review are displayed in three different categories: a) social media usage, b) factors that influence social media adoption for teaching, c) challenges in using social media for teaching. 


\section{The systematic literature review process}

The authors of this review followed the Systematic Literature review stages suggested by Tranfield, et al. (2003), adapted from The Cochrane Collaboration's Cochrane Reviewers' Handbook and the National Health Service Dissemination (2001). He provided three stages in conducting a literature review; Stage I: planning the review, Stage II: conducting the review, and Stage III: reporting and dissemination.

\section{Stage I-Planning the review}

Phase 0 - Identification for the need for a review

Petticrew and Roberts (2006) suggested a systematic literature review is an appropriate method for the following situations:

1. When research shows clear uncertainty about the effectiveness of a policy for adoption of guidelines and procedures by policy makers. Evidence for this is shown in; Rambe and Nel (2015), Sobaih, et al. (2016) and Cao, et al. (2013).

2. When there is a wide range of research on the area, but key research questions remain unanswered. This claim is supported by research from Manca and Ranieri (2016a and 2016b).

The researcher needs to decide on a definitive review question. The review question is critical to a systematic review as other aspects of the process flow from it (Tranfield et al., 2003). The review question aids in the making of key decisions such as: what types of studies to include; where to find them; how to assess their quality; and how to pool their findings. Each of these answers will affect decisions about inclusion or exclusion criteria (Gough, Oliver and Thomas, 2017).

The review question should specify the types of population (participants), types of interventions (and comparisons), and the types of outcomes that are of interest. The acronym PICO (Participants, Interventions, Comparisons and Outcomes) helps to serve as a reminder of these (Higgins and Green, 2008). Petticrew and Roberts (2006) provided a framework based on the PICOC: five components of a clear systematic review question; Population, Intervention, Comparison, Outcomes, Context (PICOC). 
Table 3: Adapted from Petticrew and Roberts (2006) and Borrego, Foster and Froyd (2014).

\begin{tabular}{|c|c|}
\hline PICOC Framework component & This systematic literature review - the answers \\
\hline $\begin{array}{l}\text { Population: Which populations are we interested in? } \\
\text { How can they best be described? Do any subgroups } \\
\text { need to be considered? }\end{array}$ & $\begin{array}{l}\text { Academics who have adopted or are adopting social } \\
\text { media within their teaching. }\end{array}$ \\
\hline $\begin{array}{l}\text { Intervention: Which intervention, activity or approach } \\
\text { should be used? }\end{array}$ & Social media adoption as an educational tool. \\
\hline $\begin{array}{l}\text { Comparison: What is/are the main alternative/s to the } \\
\text { intervention being considered? }\end{array}$ & Teaching with technology but not social media . \\
\hline $\begin{array}{l}\text { Outcome: which outcomes are the most relevant for } \\
\text { answering the question? }\end{array}$ & $\begin{array}{l}\text { The theoretical learning frameworks: utilitarian, social } \\
\text { constructivism, pragmatism. Drivers of adoption. } \\
\text { Adoption processes framework. }\end{array}$ \\
\hline $\begin{array}{l}\text { Context: what is the context within which the } \\
\text { intervention is delivered? how was the intervention } \\
\text { delivered? what aided and/or hindered its impact, how } \\
\text { the process of implementing was carried out, and what } \\
\text { factors may have contributed to its success or failure? }\end{array}$ & $\begin{array}{l}\text { The impact of the adoption of social media as an } \\
\text { educational tool } \\
\text { The factors contributed to the adoption } \\
\text { Challenges/barriers to adoption - success and failure } \\
\text { Teacher-led interventions }\end{array}$ \\
\hline
\end{tabular}

Table 3 shows a conceptual framework for this review. This framework informs and structures clear research questions and helps to establish appropriate research designs and methods. This conceptual framework may be regarded as a working hypothesis that can be advanced, refined or confirmed during research (Higgins and Green, 2008).

In Cochrane reviews, questions can be stated as review objectives, and specified in detail as criteria of inclusion and exclusion. A statement of the review's objectives should be of the form 'To assess the effects of [intervention or comparison] for [health problem] in [types of people, disease or problem and setting if specified]' (Higgins and Green, 2008). For this review the review objective can be stated as:

"To assess the progress of social media adoption as an educational tool by academics in higher education".

Review questions that focus mainly on evaluating the extent to which the intervention is effective in terms of its impacts are the most common reasons for conducting systematic reviews (Anderson et al., 2013). Petticrew and Roberts (2006, p.57) 
suggested that review questions of the form "what works?" are best answered by synthesis of quantitative studies, while review questions of the form "what matters?" are best addressed through synthesis of qualitative studies.

Table 4 includes examples of review questions for this systematic literature review.

Table 4: Review Questions

\begin{tabular}{|l|l|}
\hline What works? (quantitative) & What matters? (qualitative) \\
\hline What adoption processes support social & How is the adoption of social media as \\
media adoption within a teaching & $\begin{array}{l}\text { an educational tool by academics } \\
\text { progressing? }\end{array}$ \\
\hline strategy? & What challenges, from an academic \\
& $\begin{array}{l}\text { perspective, does the adoption of social } \\
\text { media as an educational tool raise? }\end{array}$ \\
\hline
\end{tabular}

Typical conceptual frameworks for reviews of effects specify a causal link between who the review is about (the population), what the review is about (an intervention and what it is being compared with), and the possible consequences of intervening in the lives of these people (desirable and undesirable outcomes) (Gough, Oliver and Thomas, 2017).

Phase 1 - Preparation of a proposal for a review

At the initial stages of this review process, a scoping study was conducted to assess the subject area. A search was conducted in Stella Search Trinity College Dublin. The following search terms were used; "social media" "higher education", "social media adoption" "academics". A vast variety of literature was found, which included technology enhanced learning and e-learning literature. Such studies considered cross-disciplinary perspectives and alternative ways in which technology (social media and other technology) and e-learning strategies have previously been addressed. It was decided that the main focus of this review will be on adoption challenges of social media as an educational tool in higher education. Therefore, a more specific selection of articles was carried out through the application of a number of criteria: (1) studies that specifically investigated academics experiences towards the adoption of social media in higher education (2) studies that were published in peer-reviewed highranking journals (3) studies published from 2012 to date. Originally, 16 articles were identified. After reviewing the articles, it was noted that studies published in 2012 
contained data collected from 2009/2010 and, hence, would be removed from this study as the aim of this review is to draw on recent data. Articles focused on technology adoption rather than social media adoption were also removed from this review as this review aims specifically to address the adoption of social media. Therefore, a proposal for a review of the remaining 10 studies was carried out (see appendix 1). The results of the scoping study are presented in the results section of this paper.

\section{Phase 2 - Development of a review protocol}

Similar to any research study, a systematic review needs a detailed protocol describing the process and methods that will be used and how different types of study will be located, appraised, and synthesized (Petticrew and Roberts, 2006). The term used for the specification of the characteristics of such studies is called the inclusion criteria (Higgins and Green, 2008).

The scoping study carried out in preparation for this review has helped to establish the inclusion and exclusion criteria of this review. A scoping review involves a search of the literature to determine what sorts of studies have been carried out, where they are published, in which databases they have been indexed, what sorts of outcomes they have assessed, and in which populations (Petticrew and Roberts, 2006).

The materials included in this scoping review study were composed of ten empirical studies. The studies were grouped according to the research methods employed. Among the papers selected for this review, three carried out a quantitative research method approach, five a qualitative research method. Of this latter group, two were longitudinal studies and three used a mixed methods approach (see appendix 2).

The studies carried out using quantitative methods used questionnaires and surveys. The qualitative-based research approaches included telephone interviews, selfnarrative reflections, and research interviews. Lastly, the mixed method approaches conducted interviews which were then followed by surveys.

In term of geographical distribution, three of the studies were published in Australia, two in the UK, two in Italy, one in South Africa, one in the USA and one in Egypt. Half of the studies $(n=5)$ were conducted in one university setting, two studies were conducted in three universities, and one in eight universities. One quantitative study was carried out at a national level with all academic faculty employed in the Italian higher education system which has been subject to two different publications. 
With reference to the aims of studies, most of the studies aimed at evaluating the use of social media as an educational tool by academics in higher education $(n=9)$, while only one study explores the reasons why academics stop using technology in their teaching. The majority of the studies $(n=9)$ are focused on a variety of SNSs while only one is focused on Facebook as a single social media tool.

There are at least three types of inclusion criteria: The first type is criteria for selecting databases that will be searched for articles, the second type is a set of combinations of search words (keywords) or phrases and logical connectors (AND, OR...) and the third type of criteria guides selection of articles that will be analysed (Borrego, Foster and Froyd, 2014).

The main types of databases that can be used to locate primary resources were explored and compared to those used in other SLRs studies related to the review question for this research and related to other education research related studies. The databases used for this review are the main two subject or disciplinary databases such as ERIC and Education Full Text (EBSCO) which have been used in previous SLRs reviewed in the scoping study, the two general databases mostly used in this review are Scopus and Web of Science. Academic Search Complete (EBSCO) was also added to include any business-related studies as this research is been carried out by the business school. Searching a different range of databases guarantees that relevant studies are found despite the discipline in which they were published and indexed (Borrego, Foster and Froyd, 2014).

This review will not include any grey literature, such as conference papers, books, book chapters, dissertations, theses, government documents, white papers and proposal. This review intends to be published in high ranking journals, hence only peer reviewed research will be included.

Keyword criteria

The top three keywords from the scoping review are: teaching, social media and University. For a Cochrane review, the structure of a search strategy should be based on the main concepts being examined in the review questions (Higgins and Green, 2008). To further assist in the selection of appropriate keywords for the search strategy the researcher created a table of possible key words which integrates every aspect of the review questions (see Table 5). 
Table 5: Search Terms

\begin{tabular}{|l|l|l|l|l|}
\hline Technology & Teaching \& learning & Staff & Institution & Verb \\
\hline Social Media & Teaching & Academic* & University & Adoption \\
\hline Facebook & Learning & Staff & College & Apply \\
\hline Twitter & e-learning & Teacher & Third level & Use \\
\hline LinkedIn & $\begin{array}{l}\text { Technology enhanced } \\
\text { learning }\end{array}$ & Faculty & Institution & Discontinuation \\
\hline Technology & Education & Lecturer & Higher education & Reject \\
\hline Web 2.0 & Online learning & Educator* & Executive & Implement \\
\hline Online communities & Educational technology & & Business & \\
\hline $\begin{array}{l}\text { Social networking } \\
\text { sites }\end{array}$ & & & Management & \\
\hline $\begin{array}{l}\text { Social media } \\
\text { networks }\end{array}$ & & & & \\
\hline Social networks & & & & \\
\hline Social interactions & & & & \\
\hline Internet & & & & \\
\hline Social software & & & & \\
\hline Blogs & & & & \\
\hline
\end{tabular}

Search terminology evolved over several iterations to establish a search string with the main keywords from the review questions as shown below:

("Social media" OR "web 2.0" OR "social software" OR Facebook OR Linkedln OR Twitter OR Instagram OR WhatsApp OR snapchat OR Pinterest) AND (University OR College OR "third level" OR Institution OR "Higher education" OR "executive education") AND (academ* OR staff OR teach* OR faculty OR lecturer OR educator OR professor*) AND (adopt* OR apply OR use OR discontin* OR reject OR implement) AND (teaching OR learning OR e-learning OR educat* OR technolog*)

Inclusion criteria

1. Empirical studies assessing the adoption of social media as an educational tool by academics in higher education.

2. These studies must be published in peer-reviewed high-ranking journals (at least 2 stars in the ABS ranking or ranked within 100 in the Education ranking)

3. Papers must be published from 2013 onwards

4. Papers must be published in English 


\section{Exclusion criteria}

1. Studies assessing the use of social media in schools or any other non-third level institutions.

2. Studies assessing the use of social media by students

3. Newspaper articles, letters, editorials and grey material.

\section{Results}

The synthesis of the scoping study revealed three main concepts and several subconcepts from the 10 empirical studies reviewed which are linked to the three research questions proposed for conducting the systematic literature review. This is visualised in Table 6 and described in the following sections.

\section{Social media usage}

Seven studies reported that academics are mainly using SNSs to share content material with students easily (Scott, 2013; Waycott et al., 2013; Haines, 2015; Rambe and Nel, 2015; Manca, and Ranieri, 2016a, 2016b;Shelton, 2017). For example, Manca and Ranieri (2016b) found that social media are mainly used to visualise resources, no matter what tool is considered. In three other studies, researchers found that academics use SNSs as communication tools (Prescott, 2014; Rambe and Nel, 2015; Sobaih et al., 2016). Rambe and Nel (2015) found that academics' favourable views of social media revolved around its potential to support contact with students by increasing communication and providing feedback, as well as providing support for social constructivist teaching style.

"The inclusion of digital media makes my teaching more interactive and fun for the students and encourages them to put more time on the subject" (Rambe and Nel, 2015, p.636).

This suggests that social media serves as an important vehicle for supporting interactive, social constructivist modes of teaching. However, Manca and Ranieri (2016b) suggested that the incorporation of more participatory practices into formal settings of learning can raise tensions that may prevent academics from adopting social media in their current practices and thus suggest a certain skepticism in using SNSs in as a constructivist education tool. Similarly, Manca and Ranieri (2016a) revealed that SNS's use for education means to circulate information about the course or to support communication, and that the main trend is to share rather than to creatively produce content. 


\section{Factors that influence social media adoption for teaching}

Some of the most commonly cited factors that influence the adoption of social media for teaching are privacy issues and loss of control (Waycott et al., 2013; Rambe and Nel, 2015; Manca and Ranieri, 2016a and 2016b; Sobaih et al., 2016; Shelton, 2017). Academics' are concerned about the lack of inquiry-based learning, perceived privacy violations, plagiarism and time investments needed to effectively design social mediaenhanced learning tasks (Rambe and Nel, 2015). Demographic variables such as age, gender, seniority, and scientific discipline also influenced faculty members' decisions to use SNSs for educational purposes (Scott, 2013; Manca and Ranieri, 2016b).

Cao et al. (2013) presented the only study in this review which applies a technology adoption model (TAM) framework to explain social media adoption by academics. This model modified a social media utilization model established by Cao and Hong in 2011 which incorporated the following factors: perceived usefulness, external pressure, perceived risk, social media readiness, social media utilization in teaching, tasktechnology compatibility, student satisfaction and student learning outcomes. Their results showed that task-technology compatibility of social media plays the most important role in predicting the use of social media by academics, whereas academics' skills and knowledge in using social media is not directly related to social media use. Thus, knowing how to use social media is not enough to determine its use as academics prioritise the fit between social media and subject taught prior to their decision to use social media.

\section{Challenges in using social media for teaching}

The biggest challenge for academics in adopting social media was the lack of institutional support (Waycott et al., 2013; Prescott, 2014; Rambe and Nel, 2015; Manca, and Ranieri, 2016a and 2016b; Sobaih et al., 2016; Shelton, 2017). Applying a new learning style which integrates social media in teaching required approval by policy makers in public higher education (Sobaih et al., 2016). While academics may be drawn to integrating social media into their teaching, they must adhere to the established practices and regulations of higher education institutions (Waycott et al., 2013).

Cultural resistance and pedagogical issues are other reasons why academics are not motivated to integrate social media into their teaching practices (Manca, and Ranieri, 2016b). In terms of pedagogical issues, Waycott et al.'s (2013) findings revealed 
conflict between the ideals of social learning and the values of learning which underpin traditional university assessment practices. For example, the key benefit of making a student's work visible to other students through social media is to increase social and collaborative learning, enabled by knowledge sharing, peer review and the ability to co-author content. This conflicts with traditional university assessment practices which are individualist and competitive.

Other challenges in adopting social media for teaching practices include the time investments required to prepare and design social media enhanced learning materials (Rambe and Nel, 2015; Sobaih et al., 2016). This is evidenced by the responses gathered by Rambe and Nel (2015): "Social media is very attractive for my teaching. [l just] don't know of good short videos" and "digital technology like social media is very attractive but very time consuming to design and prepare" (Rambe and Nel, 2015, p. 643).

This synthesis revealed three main concepts and several sub-concepts from the 10 reviewed studies which are linked to the three research questions proposed for this PhD study. This can be visualised in Table 6.

Table 6: Synthesis: Concepts and Research Questions.

\begin{tabular}{|c|c|c|}
\hline Concept & Sub-concept & Studies \\
\hline Social Media usage & Communication & $\begin{array}{l}\text { Prescott (2014); Rambe and Nel } \\
\text { (2015); Sobaih et al. (2016). }\end{array}$ \\
\hline \multirow[t]{3}{*}{$\begin{array}{l}\text { RQ1: How is the adoption of } \\
\text { social media as an } \\
\text { educational tool by } \\
\text { academics progressing? }\end{array}$} & $\begin{array}{l}\text { Sharing information } \\
\text { and resources } \\
\text { (improve accessibility) }\end{array}$ & $\begin{array}{l}\text { Haines (2015); Manca and Ranieri } \\
\text { (2016a, and 2016b); Rambe and Nel } \\
\text { (2015); Scott (2015); Shelton (2017); } \\
\text { Waycott et al. (2013). }\end{array}$ \\
\hline & $\begin{array}{l}\text { Student to student } \\
\text { Collaboration } \\
\text { Co-Creation }\end{array}$ & $\begin{array}{l}\text { Haines (2015); Shelton (2017); } \\
\text { Waycott et al. (2013). }\end{array}$ \\
\hline & $\begin{array}{l}\text { For assessment } \\
\text { (assessment for } \\
\text { learning) }\end{array}$ & Waycott et al (2013). \\
\hline
\end{tabular}




\begin{tabular}{|c|c|c|}
\hline & $\begin{array}{l}\text { Supports } \\
\text { constructivism } \\
\text { teaching styles }\end{array}$ & $\begin{array}{l}\text { Rambe and Nel (2015); Scott (2015); } \\
\text { Waycott et al. (2013). }\end{array}$ \\
\hline \multirow{2}{*}{$\begin{array}{l}\text { Factors that influence social } \\
\text { media adoption for teaching }\end{array}$} & Teaching style & Cao et al (2013); Prescott (2014). \\
\hline & Demographic factors & $\begin{array}{l}\text { Manca and Ranieri (2016a and } \\
\text { 2016b); Scott (2015). }\end{array}$ \\
\hline \multirow{3}{*}{$\begin{array}{l}\text { RQ2: What adoption } \\
\text { processes support social } \\
\text { media adoption within } \\
\text { teaching strategy? }\end{array}$} & Previous experience & $\begin{array}{l}\text { Manca and Ranieri (2016a and } \\
\text { 2016b); Scott (2015). }\end{array}$ \\
\hline & $\begin{array}{l}\text { Task-technology } \\
\text { compatibility }\end{array}$ & $\begin{array}{l}\text { Cao et al. (2013); Rambe and Nel } \\
\text { (2015). }\end{array}$ \\
\hline & Cultural resistance & $\begin{array}{l}\text { Manca and Ranieri (2016a and } \\
\text { 2016b); Sobaih et al. (2016); Shelton } \\
\text { (2017); Waycott et al. (2013). }\end{array}$ \\
\hline $\begin{array}{l}\text { Challenges in using social } \\
\text { media as an education tool }\end{array}$ & Pedagogical issues & $\begin{array}{l}\text { Prescott (2014) Rambe and Nel } \\
\text { (2015). Scott (2015); Sobaih et al. } \\
\text { (2016). }\end{array}$ \\
\hline \multirow[t]{3}{*}{$\begin{array}{l}\text { RQ3: What challenges does } \\
\text { the adoption of social media } \\
\text { mean from an academic } \\
\text { perspective? }\end{array}$} & $\begin{array}{l}\text { Lack of institutional } \\
\text { support }\end{array}$ & $\begin{array}{l}\text { Manca and Ranieri (2016a and } \\
\text { 2016b); Prescott (2014); Rambe and } \\
\text { Nel (2015); Shelton (2017); Sobaih et } \\
\text { al. (2016); Waycott et al. (2013). }\end{array}$ \\
\hline & Time investment & $\begin{array}{l}\text { Rambe and Nel (2015); Sobaih et al. } \\
\text { (2016). }\end{array}$ \\
\hline & Privacy issues & $\begin{array}{l}\text { Manca and Ranieri (2016a and } \\
\text { 2016b); Rambe and Nel (2015); } \\
\text { Shelton (2017); Sobaih et al. (2016); } \\
\text { Waycott et al. (2013). }\end{array}$ \\
\hline
\end{tabular}

\section{Conclusion}

This scoping review study is timely as social media as an educational tool has gained popularity amongst academics. The review of the 10 articles included in this paper was framed around three major research questions. First, the findings indicated that 
academics are slow at adopting social media within their teaching and if/when social media is used, academics use it for improving accessibility to resources or class materials. Second, knowing how to use social media for personal use is not enough to determine its use for teaching as academics are concerned about privacy issues, plagiarism and time investments needed to effectively design social media-enhanced learning tasks. Third, the biggest challenge for academics is the lack of institutional support and guidance when implanting social media within their teaching. This scoping study enlightens stage II of the SLR process, conducting the review, with well-informed criteria of inclusion and exclusion. As presented in the methodology, a detailed protocol for the methods employed going forward have been established. Keywords, databases, inclusion and exclusion criteria will be the initial protocol for conducting the systematic literature review.

The number of studies included in this review was deemed sufficient for the preparation of a review proposal to assist the development of a protocol. As with all reviews, the current study does not claim to be comprehensive, and it was carried out to understand the size and scope of a systematic review development process on the adoption challenges of social media by academics in higher education. This research area lacks substantial empirical evidence, hence the limited number of studies in this review.

\section{References}

Anderson, L. M., Oliver, S.R., Michie, S., Rehfuess, E., Noyes, J. and Shemilt, I. (2013) 'Investigating complexity in systematic reviews of interventions by using a spectrum of methods', Journal of Clinical Epidemiology, 66 (11), pp. 1223-1229.

Borrego, M., Foster, M. J. and Froyd, J. E. (2014) 'Systematic literature reviews in engineering education and other developing interdisciplinary fields', Journal of Engineering Education, 103 (1), pp. 45-76.

Cao, Y., Ajjan, H. and Hong, P. (2013) 'Using social media applications for educational outcomes in college teaching: A structural equation analysis', British Journal of Educational Technology, 44 (4), pp. 581-593.

Evans, C. (2014), 'Twitter for teaching: Can social media be used to enhance the process of learning?', British Journal of Educational Technology, 45 (5), pp. 902-915

Gough, D., Oliver, S. and Thomas, J. (2017) An Introduction to Systematic Reviews. 2nd edn. [Online]. Available at:

https://bookshelf.vitalsource.com/\#/books/9781473968226/cfi/6/2!/4/2/2@0:0 (Accessed: 10 July 2018). 
Haines, K. (2015) 'Learning to identify and actualize affordances in a new tool', Language, Learning and Technology, 19 (1), pp. 165-180.

Higgins, J. and Green, S. (2008) Cochrane Handbook for Systematic Reviews of Interventions. Wiley.

Junco, R. , Elavsky C. M. and Heiberger, G. (2013) 'Putting twitter to the test: Assessing outcomes for student collaboration, engagement and success', British Journal of Educational Technology, 44 (2), pp. 273-287.

Junco, R., Heiberger, G. and Loken, E., (2011) 'The effect of Twitter on college student engagement and grades', Journal of Computer Assisted Learning, 27 (2), pp. 119-132.

Jung, I. and Lee, Y. (2015) 'YouTube acceptance by university educators and students: a cross-cultural perspective', Innovations in Education \& Teaching International, 52 (3), pp. 243-253.

Kaplan, A. M. and Haenlein, M. (2010) 'Users of the world, unite! The challenges and opportunities of Social Media', Business Horizons, 53 (1), pp. 59-68.

Manca, S. and Ranieri, M. (2016a) "'Yes for sharing, no for teaching!": Social Media in academic practices', Internet and Higher Education, 29, pp. 63-74.

Manca, S. and Ranieri, M. (2016b) 'Facebook and the others. Potentials and obstacles of Social Media for teaching in higher education', Computers \& Education, 95, pp. 216-230.

Manca, S. and Ranieri, M. (2013) 'Is it a tool suitable for learning? A critical review of the literature on Facebook as a technology-enhanced learning environment', Journal of Computer Assisted Learning, 29 (6), pp. 487-504.

Manca, S., Ranieri, M. and Manca S., R. M. (2016c) 'Is Facebook still a suitable technologyenhanced learning environment? An updated critical review of the literature from 2012 to 2015', Journal of Computer Assisted Learning, 32 (6), pp. 503-528.

Nkhoma, M., Cong, H.P., Lam, T., Richardson, J., Smith, R. and El-Den, J. (2015) 'Facebook as a tool for learning purposes: Analysis of the determinants leading to improved students' learning', Active Learning in Higher Education, 16 (2), pp. 87-101.

Petticrew, M. and Roberts, H. (2006) Systematic Reviews in the Social Sciences: A Practical Guide. Blackwell.

Prescott, J. (2014) 'Teaching style and attitudes towards Facebook as an educational tool', Active Learning in Higher Education, 15 (2), pp. 117-128.

Rambe, P. and Nel, L. (2015) 'Technological utopia, dystopia and ambivalence: Teaching with social media at a South African university', British Journal of Educational Technology, 46 (3), pp. 629-648. 
Scott, K. M. (2013) 'Does a university teacher need to change e-learning beliefs and practices when using a social networking site? A longitudinal case study', British Journal of Educational Technology, 44 (4), pp. 571-580.

Shelton, C. (2017) 'Giving up technology and social media: why university lecturers stop using technology in teaching', Technology, Pedagogy and Education, 26 (3), pp. 303-321.

Sobaih, A.E.E., Moustafa, M.A., Ghandforoush, P. and Khan, M. (2016) 'To use or not to use? Social media in higher education in developing countries', Computers in Human Behavior, 58, pp. 296-305.

Tess, P. A. (2013) 'The role of social media in higher education classes (real and virtual) - A literature review', Computers in Human Behavior, 29 (5), pp. A60-A68.

Tranfield, D., Denyer, D. and Smart, P. (2003) 'Towards a Methodology for Developing Evidence-Informed Management Knowledge by Means of Systematic Review, British Journal of Management, 14 (3), pp. 2017-222.

Waycott, J., Sheard, J., Thompson, C., Clerehan, R. (2013) 'Making students' work visible on the social web: A blessing or a curse?', Computers \& Education, 68, pp. 86-95. 
Appendix One: Summary of empirical studies for the Scoping study.

\begin{tabular}{|c|c|c|c|c|c|c|}
\hline Study & $\begin{array}{l}\text { Journal/ } \\
\text { Ranking }\end{array}$ & $\begin{array}{l}\text { Theoretical } \\
\text { Framework }\end{array}$ & Methodology & Data Sources & Participants & Major Findings \\
\hline $\begin{array}{l}\text { Cao, Ajjan } \\
\text { and Hong } \\
(2013)\end{array}$ & $\begin{array}{l}\text { British Journal of } \\
\text { Educational } \\
\text { Technology } \\
\text { Rank } 50\end{array}$ & $\begin{array}{l}\text { Bloom's } \\
\text { Taxonomy and } \\
\text { TAM model }\end{array}$ & Mixed-method & $\begin{array}{l}\text { Interviews and } \\
\text { Surveys }\end{array}$ & $\begin{array}{l}168 \text { faculty } \\
\text { members for } \\
\text { survey/12 } \\
\text { faculty } \\
\text { members for } \\
\text { interviews }\end{array}$ & $\begin{array}{l}\text { The decision on social media use by faculty is highly } \\
\text { dependent on external pressure, perceived } \\
\text { usefulness, perceived risk and task-technology } \\
\text { compatibility, this last one being the most important } \\
\text { one. They consider social media applications and the } \\
\text { subject taught prior their decision. the study proves } \\
\text { the use of social media provides better learning } \\
\text { outcomes and better satisfaction to students. The } \\
\text { results indicate that management must work with } \\
\text { faculty to identify the SM that fit specific subjects and } \\
\text { teaching styles and match them with appropriate } \\
\text { training. }\end{array}$ \\
\hline $\begin{array}{l}\text { Haines } \\
(2015)\end{array}$ & $\begin{array}{l}\text { Language } \\
\text { Learning \& } \\
\text { technology } \\
\text { Rank } 109\end{array}$ & None & Qualitative & $\begin{array}{l}\text { Semi- } \\
\text { structured } \\
\text { interviews }\end{array}$ & $\begin{array}{l}16 \text { language } \\
\text { teachers in } \\
\text { university } \\
\text { but focused } \\
\text { on two } \\
\text { teachers }\end{array}$ & $\begin{array}{l}\text { This study interviewed } 3 \text { times over } 14 \text { months data } \\
\text { collection two language teachers which were the most } \\
\text { experienced with digital technologies in the classroom } \\
\text { for } 15 \text { years. They were asked to reflect on their use } \\
\text { of new tools blogs and wikis. Three main points raised } \\
\text { from both teachers' in terms of developing their } \\
\text { understanding of affordance were: Perceptions of } \\
\text { learning affordance develop over time and through } \\
\text { experimenting and through informal means rather } \\
\text { than informally. These perceptions differ between } \\
\text { individual teachers as it is influenced by their beliefs } \\
\text { about how best to support learning process. They } \\
\text { may also perceive affordances in the use of }\end{array}$ \\
\hline
\end{tabular}




\begin{tabular}{|c|c|c|c|c|c|c|}
\hline & & & & & & $\begin{array}{l}\text { technology for their personal learning and } \\
\text { professional development. }\end{array}$ \\
\hline $\begin{array}{l}\text { Manca and } \\
\text { Ranieri } \\
\text { (2016a) }\end{array}$ & $\begin{array}{l}\text { Internet and } \\
\text { higher education } \\
\text { Rank } 16\end{array}$ & None & Quantitative & Survey & $\begin{array}{l}6139 \text { faculty } \\
\text { members }\end{array}$ & $\begin{array}{l}\text { The study provides an analysis of academic staff uses } \\
\text { of Social Media and the relationship between them. } \\
\text { Faculty members are more inclined to adopt Social } \\
\text { Media for personal sharing and professional } \\
\text { connections with peers than to incorporate these tools } \\
\text { in their teaching practices. Like previous technologies } \\
\text { (e.g., computer and the Internet), Social } \\
\text { Media do not seem to easily fit within pre-existing } \\
\text { instructional practices and their adoption would } \\
\text { require investment of time in a situation where } \\
\text { teaching is less valued than research for professional } \\
\text { career } \\
\text { development. There are exceptions, such as } \\
\text { Podcasts or SlideShare, which seem to confirm this } \\
\text { general trend, since both Podcasts or SlideShare are } \\
\text { content delivery tools that can more easily be adapted } \\
\text { to the traditional lecturing model which still prevails in } \\
\text { universities }\end{array}$ \\
\hline $\begin{array}{l}\text { Manca and } \\
\text { Ranieri } \\
(2016 b)\end{array}$ & $\begin{array}{l}\text { Computers \& } \\
\text { Education } \\
\text { Rank } 15\end{array}$ & None & Quantitative & Survey & $\begin{array}{l}6139 \text { faculty } \\
\text { members }\end{array}$ & $\begin{array}{l}\text { Social media has a low level of faculty adoption. } 40 \% \\
\text { using at least one tool on a monthly basis and less } \\
\text { than } 40 \% \text { declaring that SM are useful for teaching } \\
\text { purposes. Gender has a limited impact on decision to } \\
\text { use SM for teaching. Males preferred twitter and } \\
\text { females the use of podcasts, you tube vimeo research } \\
\text { gate academia.edu and slideshare. FB and Twitter } \\
\text { are used by younger academics and mainly used to } \\
\text { motivate students. Blogs/wikis, podcasts, youtube } \\
\text { vimeo, slideshare and research gate and } \\
\text { academia.edu are seen to improve the quality of } \\
\text { teaching or to share educational content. Academics }\end{array}$ \\
\hline
\end{tabular}




\begin{tabular}{|c|c|c|c|c|c|c|}
\hline & & & & & & $\begin{array}{l}\text { are using FB and blog-wiki to prepare their lectures } \\
\text { and to support collaborative work among students. } \\
\text { Twitter and Linkedln were used to circulate info about } \\
\text { the course and to encourage community building. } \\
\text { Perceived usefulness is an important factor that } \\
\text { motivates the use of SM and perceived risk affects } \\
\text { motivation to use them, i.e. the issue of privacy, the } \\
\text { management of relationships with students. }\end{array}$ \\
\hline $\begin{array}{l}\text { Prescott } \\
(2014)\end{array}$ & $\begin{array}{l}\text { Active learning } \\
\text { in higher } \\
\text { education } \\
\text { Rank } 100\end{array}$ & $\begin{array}{l}\text { Teacher- } \\
\text { centered and } \\
\text { learner- } \\
\text { centered } \\
\text { (only } \\
\text { mentioned) }\end{array}$ & Quantitative & Survey & $\begin{array}{l}172 \text { faculty } \\
\text { educators }\end{array}$ & $\begin{array}{l}\text { Findings suggest that faculty use FB for their social } \\
\text { lives, and few of them use it within their teaching. } \\
\text { Those who use FB within their teaching do for } \\
\text { communicating and sharing information and } \\
\text { resources with students rather than more formal } \\
\text { learning. Therefore the way staff use FB for their } \\
\text { teaching is consistent with the informal learning } \\
\text { approach. }\end{array}$ \\
\hline $\begin{array}{l}\text { Rambe and } \\
\text { Nel (2015) }\end{array}$ & $\begin{array}{l}\text { British Journal of } \\
\text { Educational } \\
\text { Technology } \\
\text { Rank } 50\end{array}$ & None & Qualitative & Observation & 12 educators & $\begin{array}{l}\text { Educators' generally favorable reports on social } \\
\text { media articulated its capacity to breach social media } \\
\text { distance between them and students, support } \\
\text { communication between student-educator, foster } \\
\text { socio-constructivist teaching through the sharing of } \\
\text { teaching materials and professional identities, and } \\
\text { develop intellectual capital through the strengthening } \\
\text { of affinity and interest-based networks. Some } \\
\text { negative perceptions of social media were related to } \\
\text { infrastructure constrains, time investments and the } \\
\text { distractive nature of social media. Complexity and } \\
\text { uncertainty of teaching with social media persisted, } \\
\text { academics complained about difficulties in locating } \\
\text { pedagogically appropriate learning materials and a }\end{array}$ \\
\hline
\end{tabular}




\begin{tabular}{|c|c|c|c|c|c|c|}
\hline & & & & & & $\begin{array}{l}\text { lack of appropriate media channels for teaching and } \\
\text { watching digital videos }\end{array}$ \\
\hline Scott (2013) & $\begin{array}{l}\text { British Journal of } \\
\text { Educational } \\
\text { Technology } \\
\text { Rank } 50\end{array}$ & None & $\begin{array}{l}\text { Qualitative } \\
\text { Longitudinal } \\
\text { study }\end{array}$ & $\begin{array}{l}\text { Interviews } \\
2 \text { years }\end{array}$ & 1 academic & $\begin{array}{l}\text { Examined one academic transition from face to face } \\
\text { to blended learning using LMS and then an SNS, } \\
\text { Ning and Facebook. Heidi (the academic) change in } \\
\text { beliefs and practices was due to reflection, discussion } \\
\text { and collaboration with colleagues. She carried out an } \\
\text { interactive process involving evaluation. Age and prior } \\
\text { experience affected Heidi's adopting an SNS such as } \\
\text { Facebook. This study demonstrated the value of } \\
\text { using longitudinal research for examining change in e- } \\
\text { learning beliefs and practices. }\end{array}$ \\
\hline $\begin{array}{l}\text { Shelton } \\
(2017)\end{array}$ & $\begin{array}{l}\text { Technology, } \\
\text { Pedagogy and } \\
\text { Education } \\
\text { Rank } 94\end{array}$ & None & Qualitative & Interviews & 11 lecturers & $\begin{array}{l}\text { This study reveals that lecturers sometimes give up } \\
\text { using a technology when new technologies appear } \\
\text { and after unsuccessful experiences and that this may } \\
\text { or may not be a voluntary decision. Furthermore, } \\
\text { lecturers interviewed have also ceased the use of } \\
\text { social media, the wider context of developments in } \\
\text { how students used technology in their lives outside of } \\
\text { teaching was perceived as a reason for the failure of } \\
\text { discussion forums and later FB as social learning } \\
\text { spaces. Students feel uncomfortable if they believe } \\
\text { their social life and study life are being blended and } \\
\text { that they may be concerned about their privacy. }\end{array}$ \\
\hline $\begin{array}{l}\text { Sobaid, } \\
\text { Moustafa } \\
\text { and } \\
\text { Ghandforous } \\
\text { h (2016) }\end{array}$ & $\begin{array}{l}\text { Computers in } \\
\text { Human Behavior } \\
3^{*}\end{array}$ & None & Mixed method & $\begin{array}{l}\text { Survey and in- } \\
\text { depth } \\
\text { interviews }\end{array}$ & $\begin{array}{l}86 \\
\text { professors } \\
\text { for survey } \\
\text { and } 27 \\
\text { professors }\end{array}$ & $\begin{array}{l}\text { This study confirms that hospitality and tourism faculty } \\
\text { agreed that social media has substantial value for use } \\
\text { for academic-related purposes particularly as a } \\
\text { learning tool. However, the actual use was at a } \\
\text { minimal level and they identified } 11 \text { barriers for the }\end{array}$ \\
\hline
\end{tabular}




\begin{tabular}{|c|c|c|c|c|c|c|}
\hline & & & & & $\begin{array}{l}\text { for } \\
\text { interviews }\end{array}$ & $\begin{array}{l}\text { use of social media for academic-related purposes: } \\
\text { privacy and security, time commitment, loss of control } \\
\text { and monitoring, digital divide, variation in mobile } \\
\text { services, grading and assessment integration with } \\
\text { LMS, institution support, infrastructure, ethical issues } \\
\text { and awareness by students on how to use social } \\
\text { media as a teaching and learning tool. This study } \\
\text { concludes supporting that social media encourages } \\
\text { students to communicate, collaborate, participate and } \\
\text { create in-depth learning through interaction. Higher } \\
\text { education institutions need to embrace today's } \\
\text { learning and shift to new era of social learning where } \\
\text { learning is student-center and the role of educators } \\
\text { are coaching and mentoring. }\end{array}$ \\
\hline $\begin{array}{l}\text { Waycott, } \\
\text { Sheard, } \\
\text { Thompson } \\
\text { and } \\
\text { Clerehan } \\
\text { (2013) }\end{array}$ & $\begin{array}{l}\text { Computers \& } \\
\text { Education } \\
\text { Rank } 15\end{array}$ & None & Qualitative & Interviews & 20 lecturers & $\begin{array}{l}\text { This study addresses the use of social web } \\
\text { technologies for student assessment in higher } \\
\text { education by mainly using blogging, and wikis to } \\
\text { make students work visible to others. The research } \\
\text { shows that this has clear opportunities for teaching } \\
\text { and learning but lecturers need to develop strategies } \\
\text { to avoid conflict between the ideals of social learning } \\
\text { and the practicalities of assessment policy and } \\
\text { procedures, for example felt others can steal their } \\
\text { work and they feel vulnerable representing } \\
\text { themselves online. }\end{array}$ \\
\hline
\end{tabular}




\section{Appendix Two: Demographics of empirical studies}

\begin{tabular}{|c|c|c|c|c|}
\hline $\begin{array}{l}\text { Research } \\
\text { Method }\end{array}$ & Geographical area & Setting & $\begin{array}{l}\text { Social Media } \\
\text { Investigated }\end{array}$ & Aims \\
\hline \multirow{3}{*}{ Quantitative } & UK & One university & $\begin{array}{l}\text { Single } \\
\text { Facebook }\end{array}$ & $\begin{array}{l}\text { Evaluate how teaching } \\
\text { staff use Facebook and } \\
\text { their attitudes towards } \\
\text { Facebook and online } \\
\text { professionalism, in terms } \\
\text { of student-staff } \\
\text { relationship. }\end{array}$ \\
\hline & Italy & $\begin{array}{l}\text { All academic } \\
\text { faculty } \\
\text { employed in the } \\
\text { Italian higher } \\
\text { education } \\
\text { system }\end{array}$ & Multiple & $\begin{array}{l}\text { Identify the uses of social } \\
\text { media in the field of } \\
\text { university teaching } \\
\text { practices }\end{array}$ \\
\hline & Italy & $\begin{array}{l}\text { All academic } \\
\text { faculty } \\
\text { employed in the } \\
\text { Italian higher } \\
\text { education } \\
\text { system }\end{array}$ & Multiple & $\begin{array}{l}\text { Provide empirical } \\
\text { evidence on how higher } \\
\text { education scholars are } \\
\text { using social media for } \\
\text { personal, teaching and } \\
\text { professional purposes. }\end{array}$ \\
\hline \multirow{5}{*}{ Qualitative } & Australia & $\begin{array}{l}\text { Three } \\
\text { Universities }\end{array}$ & Multiple & $\begin{array}{l}\text { Identify the implications } \\
\text { for learning and teaching } \\
\text { that emerge when } \\
\text { students' assessable } \\
\text { work is made visible to } \\
\text { others via social media. }\end{array}$ \\
\hline & Australia & One university & Multiple & $\begin{array}{l}\text { Examines how one } \\
\text { teacher changed from } \\
\text { teaching fully face to face } \\
\text { to teaching blended } \\
\text { learning, initially using a } \\
\text { LMS, then an SNS }\end{array}$ \\
\hline & South Africa & One university & Multiple & $\begin{array}{l}\text { Explores the use of social } \\
\text { media by Computer } \\
\text { Science and Informatics } \\
\text { educators to unravel how } \\
\text { their perceptions of social } \\
\text { media informs their } \\
\text { pragmatic instructional } \\
\text { uses of these } \\
\text { technologies. }\end{array}$ \\
\hline & UK & $\begin{array}{l}\text { Three } \\
\text { universities }\end{array}$ & Multiple & $\begin{array}{l}\text { Explores why university } \\
\text { lecturers stop using } \\
\text { technology. This included } \\
\text { Facebook as an up-to- } \\
\text { date or innovative } \\
\text { technology or practices }\end{array}$ \\
\hline & Australia & One university & Multiple & $\begin{array}{l}\text { Describes the } \\
\text { perceptions of the } \\
\text { affordances of two } \\
\text { computer-mediated } \\
\text { communication (CMC) } \\
\text { tools (blogs and wikis) } \\
\text { developed over time by } \\
\text { two language university } \\
\text { teachers. }\end{array}$ \\
\hline $\begin{array}{l}\text { Mixed } \\
\text { Method }\end{array}$ & Egypt & $\begin{array}{l}\text { Eight higher } \\
\text { educational } \\
\text { institutions }\end{array}$ & Multiple & $\begin{array}{l}\text { Examines the value and } \\
\text { use of social media as } \\
\text { effective teaching and } \\
\text { learning tool in higher }\end{array}$ \\
\hline
\end{tabular}




\begin{tabular}{|l|l|l|l|l|}
\hline & & & $\begin{array}{l}\text { education in developing } \\
\text { countries }\end{array}$ \\
\cline { 2 - 4 } & USA & One university & Multiple & $\begin{array}{l}\text { Examines the value and } \\
\text { use of social media as } \\
\text { effective teaching and } \\
\text { learning tool in higher } \\
\text { education in developing } \\
\text { countries. }\end{array}$ \\
& & $\begin{array}{l}\text { Focuses on the } \\
\text { educational outcomes } \\
\text { and examined a research } \\
\text { model of antecedents } \\
\text { and consequences of } \\
\text { social media use. }\end{array}$ \\
\hline
\end{tabular}

153 